\title{
Collusive bidding in Brazilian infrastructure projects
}

Regis Signor Dr. Eng.

Forensic Expert, Federal Police, Florianópolis, Brazil

Peter E. D. Love ScD, PhD

John Curtin Distinguished Professor, Department of Civil Engineering,

Curtin University, Perth, Australia (corresponding author:

p.love@curtin.edu.au) (Orcid:0000-0002-3239-1304)

\author{
Oluwole Olatunji PhD \\ Senior Lecturer, Department of Construction Management, \\ Curtin University, Perth, Australia \\ João J. C. B. Vallim Eng. \\ Forensic Expert, Federal Police, Curitiba, Brazil \\ Alexandre B. Raupp Msc. Eng. \\ Forensic Expert, Federal Police, Florianópolis, Brazil
}

Allegations of corruption have resulted in an investigation of Brazil's national 'oil' company prior to an incumbent Brazilian president disputing their re-election. The investigation has examined allegations that several directors of the 'state'-owned company received bribes from construction companies and that the funds were used to support the parties of the governing coalition. Using a case study, this paper presents the approach adopted by the Brazilian Federal Police to determine if collusion had occurred. The bidding patterns of construction firms in 22 infrastructure projects suggested to the police that collusion occurred. Considering these circumstances, 561 bids for 77 projects were examined. Investigators obtained evidence that indicates that a collusive behaviour regarding procurement at specific construction firms (the League of 16) had taken place. The conclusions of the research provide insights into the intendment of the League of 16 's bidding patterns with an example of the 'real' cost of cartelisation that was experienced in an infrastructure project.

\author{
Notation \\ $A^{2} \quad$ Anderson-Darling statistic \\ D Kolmogorov-Smirnov statistic \\ $\mathrm{H}_{0} \quad$ null hypothesis \\ $\mathrm{H}_{1} \quad$ alternative hypothesis \\ $n \quad$ sample size \\ $n_{1} \quad$ size of League of 16 bids dataset \\ $n_{2} \quad$ size of competitive bids dataset \\ $P \quad$ probability of occurrence \\ $s \quad$ sample standard deviation \\ $s_{1} \quad$ sample of League of 16 bids standard deviation \\ $s_{2} \quad$ sample of competitive bids standard deviation \\ $t \quad$ student's $t$ statistic \\ $t_{\text {crit }} \quad$ critical value for the student's $t$ statistic \\ $\bar{x}$ sample mean \\ $\bar{x}_{1} \quad$ sample of League of 16 bids mean \\ $\bar{x}_{2} \quad$ sample of competitive bids mean \\ $\alpha \quad$ significance level \\ $\mu \quad$ population mean \\ $\mu_{1} \quad$ population of League of 16 bids mean \\ $\mu_{2} \quad$ population of competitive bids mean \\ $\sigma \quad$ population standard deviation \\ $\chi^{2} \quad$ chi-square statistic
}

\section{Introduction}

Top [...] officials are accused of colluding with a cartel of construction and engineering firms to agree to overpriced contracts for major work that would be paid for by the state-run company's multibillion-dollar budget. Federal prosecutors say the cartel then channeled the excess cash back to [the State-run oil company's] officials and divided up the work themselves. The officials allegedly took cuts of those bribes, but passed much of the rest of it to dozens of politicians and several major political parties to be used in election campaigns. (Sandy, 2016)

Brazil is a democratic society and the seventh largest economy in the world based on nominal gross domestic product (GDP). From 2000 to 2012, Brazil had an average annual GDP growth rate of over $5 \%$ and was one of the fastest-growing major economies. However, despite economic growth, the Brazilian public has been vocal about the repeated occurrence of infrastructure projects experiencing increases in their budget; as a result, this has adversely impacted investment in education and healthcare, which is desperately needed. This position has not arisen due to poor control or mismanagement of funds, which has often been espoused in studies explaining increases in the budget of infrastructure projects (e.g. Flyvbjerg, 2016).

An investigation being carried out by the Brazilian Federal Police on widespread corruption is being undertaken and was started in March 2014. It initially focused on a money laundering investigation and has subsequently been expanded to examine other allegations of corruption at a state-run oil company (henceforth, the 'oil' company). Here it has been alleged that executives accepted bribes in return for awarding contracts to construction firms at inflated prices (Brazilian Federal Police, 2016).

The investigation has uncovered corruption, embedded within the fabric of the national 'oil' company's procurement practices. Investigators have obtained evidence that explicitly indicates a collusive behaviour among specific construction firms (referred to as the League of 16). Juxtaposed with some politicians and administrative employees from the 'oil' company, several 
construction firms have been involved in the 'overpricing' of infrastructure projects that have been constructed. Up until April 2016, 572 mandates to search and seize documents and assets and 153 conduction and 154 arrest warrants had been deployed by the Brazilian Federal Police Force. According to Rosas (2015), the lead federal prosecutor estimated that the damage caused by the perpetrators in this ongoing case will exceed $\mathrm{R} \$ 20$ billion (approximately US $\$ 9 \cdot 8$ billion). Several court decisions have initially found the defendants guilty, although appeals are now in process and with the courts; case numbers include 508337605.2014.4.04.7000/ PR, 508336051.2014.4.04.7000/PR, 508335189.2014.4.04.7000/PR, 508340118.2014.4.04.7000/PR and 508325829.2014.4.04.7000/PR.

Many of the construction firms and public officials involved in the case have admitted guilt and entered into plea bargains. Brazil's second largest construction firm, for example, agreed to return US\$285 million to the government as result of a co-operation agreement with the Justice Ministry. Executives from this firm have admitted to paying bribes to politicians for contracts with the 'oil' company and other public projects (Agencia EFE, 2016). Such projects included soccer stadiums for the 2014 Fédération Internationale de Football Association World Cup, the Angra 3 nuclear power plant and Belo Monte hydroelectric power plant. Construction firms and public officials have begun to assist investigators to uncover how a self-denominated League of 16 cartel wilfully agreed to overprice infrastructure projects. While the Federal Police have believed that this organised criminal behaviour has existed for a significant period of time, prosecution teams have struggled to provide courts with the necessary independent evidence to unearth the existence of overpricing (Signor et al., 2016a, 2016b).

Determining the presence of overpricing has been, and still remains, an arduous task for the Federal Police (Lopes, 2011). However, a way to detect the cartel's existence and their collusive behaviour is to compare their bidding behaviour and outcomes to those of construction firms that have not taken part in the collusion. The literature is replete with research that examines bidding practices and the determination of collusion (e.g. Brown and Loosemore (2015), Chotibhongs and Arditi (2012), Le et al. (2014), Zarkada-Fraser and Skitmore (2000)). Nonetheless, there is a paucity of real-life cases presented from the experiences obtained from those 'on-the-ground personnel' investigating corrupt practices. Due to the sheer volume of research that has examined corruption in construction, it is beyond the scope and context of the case study presented in this paper to provide a detailed review. However, a detailed review of corruption in construction can be found in the works of Bowen et al. (2012), Brown and Loosemore (2015), Ko and Weng (2011), Le et al. (2014), Sexton (1989), Sohail and Cavill (2008) and Zhang et al. (2016).

With this in mind, this paper provides insights into the largest corruption scandal, in dollar terms, ever identified in any democracy. This paper presents the scientific approach used by the Brazilian Federal Police to pinpoint the overpricing behaviour and outcomes of the League of 16 construction firms. The research draws its conclusions by providing insights into the intendment of the League of 16's bidding patterns with an example of the 'real' cost of cartelisation that was experienced and is extrapolated from an infrastructure project. Insights provided in this paper offer a unique opportunity to learn from the experiences of the Brazilian Federal Police in detecting overpricing and collusive behaviour when procuring infrastructure projects.

\section{Uncovering the national 'oil' company's bidding process}

Brazil's national 'oil' company, which is the world's sixth biggest energy firm when their asset values are considered, is involved in the exploration, production, refining and sale of oil, gas and energy and forms the backbone of the Brazilian economy (Barnato, 2014). For decades, the 'oil' company has made a series of major investments in the construction of major petrochemical infrastructure in Brazil.

The 'oil' company starts its bidding processes by defining a project's scope, and then an in-house team prepares an initial estimate of the expected construction costs. Thereafter, bids are administered by the 'oil' company by way of selective tendering; invitations are distributed to selected companies based on previous relationships or based on the capacity of the potential bidder in a particular line of expertise. Furthermore, the 'oil' company's rules often limit invitations to national firms, which reduces the number of bids for a project. A key finding that has emerged from 'Operation Car Wash' is that bidders may be invited for political reasons rather than their technical capability and competence.

The 'oil' company advertises that it does not have an obligation to accept the lowest bids, accepting only those within the range of -15 to $+20 \%$ relative to their own estimate. Prices above these limits are considered anomalous and excluded from the tender process. In cases where the prices are below the lowest limit, the 'oil' company may request the bidder to ratify its bid and then the company considers whether or not to accept the proposed price. In an event where bidders have identified significant errors in the 'oil' company's estimates, or vice versa, deliberations around the initial estimates may take place.

The Federal Police's forensic experts have revealed that in cases where collusion has been suspected, mostly in large projects ( $>$ R $\$ 100$ million or approximately US\$49 million), only the League of 16 firms had provided bids. In most of the 22 projects initially examined, it was revealed that 15 had the same pattern of bidding, in which winning bids were very close to or more than $20 \%$ above the 'oil' company's in-house estimates and all the others were 'cover bids'. Notably, a detailed examination on the methods used for determining non-competitive bids can be found in the papers of Lai et al. (2004) and Skitmore (2000). In some instances, there is evidence to suggest that the cartel colluded to offer prices that were significantly higher than the 'oil' company's original estimate. This approach abetted colluders to force upward reviews of the 'oil' 


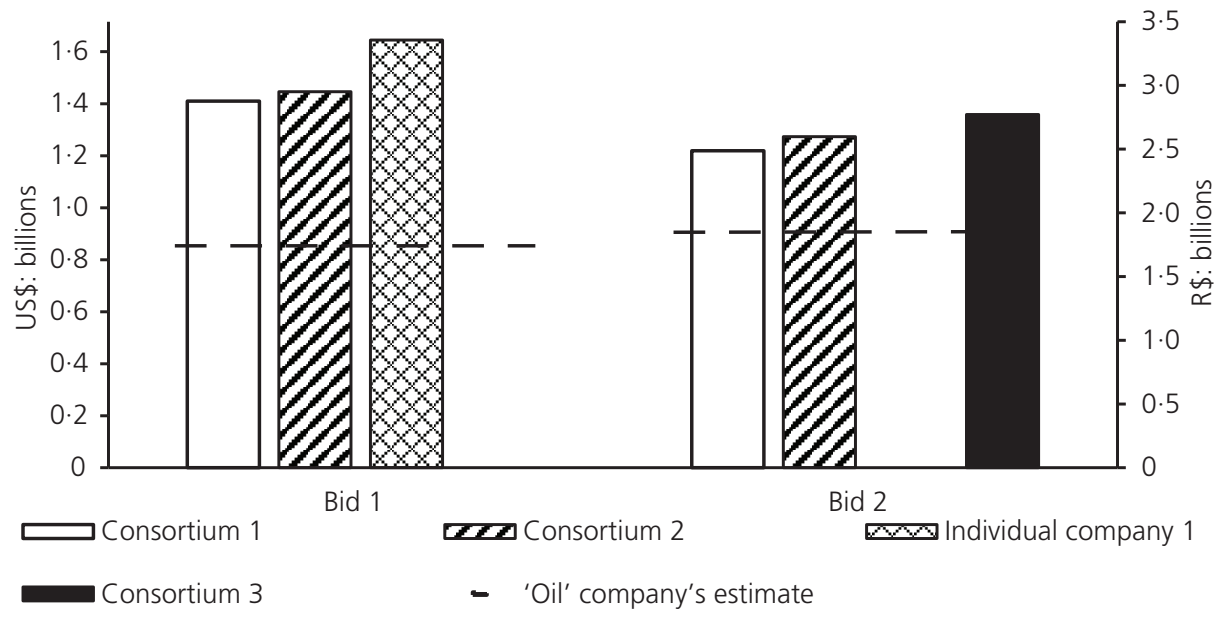

Figure 1. Bidding distribution exemplar illustrating how collusive bidders forced an upward review of the 'oil' company's in-house estimates

company's estimates such that the bidding process must be repeated. The cycle continued until the cabal's goals were met. Figure 1 exemplifies this modus operandi - derived from a particular project identified by the experts investigating the case.

In this example, it was revealed that the League of 16 had submitted bids that were far above the 'oil' company's estimate. In both the bid and the rebid rounds, the 'oil' company had to review its estimates. After the rebid, this project was directly contracted for $\mathrm{R} \$ 1.94$ billion (approximately US\$950 million) to consortium 1.

\section{Determining collusion: the Organisation for Economic Co-operation and Development indicators}

Federal Police forensic investigators have observed that a representative part of the 'oil' company's bids were considerably high when compared to others. This initial observation meets one of the parameters set by the Organisation for Economic Co-operation and Development (OECD, 2009: p. 1) in analysing cases where collusion has been suspected

Bid rigging (or collusive tendering) occurs when businesses, that would otherwise be expected to compete, secretly conspire to raise prices or lower the quality of goods or services for purchasers who wish to acquire products or services through a bidding process. Public and private organizations often rely upon a competitive bidding process to achieve better value for money. Low prices and/or better products are desirable because they result in resources either being saved or freed up for use on other goods and services. The competitive process can achieve lower prices or better quality and innovation only when companies genuinely compete (i.e., set their terms and conditions honestly and independently). Bid rigging can be particularly harmful if it affects public procurement. Such conspiracies take resources from purchasers and taxpayers, diminish public confidence in the competitive process, and undermine the benefits of a competitive marketplace.
According to the OECD (2009: p. 2), collusion often occurs when a stable market that has limited or no new entrants is dominated by only a few players, and when major industry associations are misused. Moreover, the OECD underlines repetitive bidding as an incentive for collusion, as well as when products and services are identical, when there are few if any substitutes and when little or no technological change is verified for the product or service. In the present case involving the League of 16 construction firms, it appears the OECD indicators of collusion became present. All the suspected bids received involved a small number of bidders; possible competitors were prevented by strategic requirements and qualifications that favoured only the League of 16 . In addition, investigators found that all the suspected perpetrators provided similar types of service and there was a paucity of alternatives provided.

According to the OECD (2009), collusion may also occur when competitors are prone to collaborate and present joint proposals (e.g. in a consortium), even though each organisation may individually have the capacity to deliver the outcomes that are required satisfactorily. Furthermore, other indicators of collusion that have been identified include (OECD, 2009)

- the submission of identical tenders or the prices submitted by bidders increase in regular increments

- a tenderer manifests irregular pricing pattern - for example, proposes rates that are significantly different for the same items, in identical or similar projects

- the same forms of collusion (e.g. bid rotation, bid suppression, cover pricing and market allocation) are perpetrated around the same clients or project types.

As part of their ongoing investigation, investigators have found that these attributes were present in several tenders of the 'oil' company's processes. In all cases examined, the same set of bidders' proposals was found to be akin in nature (i.e. all were 
significantly higher than the estimated market value). Evidence that had also been accumulated indicated that a consortium had been formed, which comprised the country's largest construction/ engineering firms that were capable of submitting independent proposals. In addition, the winning bids (from the League of 16 cartel) were significantly higher than tenders submitted by the same bidders in unfettered bids, either as a consortium or individually. Moreover, evidence has revealed that there had been a proclivity for losing tenders to have been submitted as 'cover' prices. For these reasons, the investigators have concluded that in accordance with the OECD's indicators, collusion had taken place with the 'oil' company and the member construction firms of the League of 16 .

While the investigators deemed that collusion had arisen, the evidence was merely circumstantial; to obtain a conviction, courts require an explicit and convincing burden of persuasion beyond the level of preponderance. Furthermore, the evidence that had been obtained in the investigation did not provide an indication of the probable losses to the 'oil' company and the state of Brazil. According to the OECD (2002: p. 1)

\footnotetext{
It is not easy to quantify these effects, however. It would require comparison of the actual market situation under the cartel to that which would exist in a hypothetical competitive market. Competition officials usually do not undertake to make such a calculation, both because it is difficult to do and because their laws usually do not require it. When an estimate of harm is necessary, however, most officials employ a proxy, which is the unlawful gain accruing to the cartel members from their activity. In its simplest form, this estimation is the product of the cartel 'mark-up' above the competitive price and the commerce affected (in units) by the cartel agreement. Even this calculation can be difficult, as it requires an assessment both of the amount of 'affected commerce' and of what the 'competitive' price would have been absent the agreement.
}

\section{Cost of collusion in infrastructure procurement}

Collusion within the construction industry is a global and ubiquitous problem (e.g. Brown and Loosemore (2015), Chotibhongs and Arditi (2012), Dorée (2004), Lai et al. (2004), Le et al. (2014)). For example, the Competition Commission in Hong Kong has suspected that bid rigging has been rife within the residential renovation and maintenance market for many years, but they have had no proof such activities have been taking place (Yau, 2016). Being able to prove collusive bidding has become a pervasive problem for governments and their respective legal jurisdictions worldwide.

In 2001, however, the Netherlands uncovered a cartel that existed within its public procurement system. According to Priemus (2004), the arranged sharing of markets by the building companies, using concealed competitive tendering, appeared to be a norm. Furthermore, Dorée (2004: p. 148) suggested that the group of contractors made no attempt to deny the reality of the cartels and bid rigging that had occurred. Thus, seen as systemic issues, a parliamentary committee was formed to investigate the issues and to recommend solutions. The committee found an average difference of $8.8 \%$ between cartelised and non-cartelised tenders. The recommendation provided by the committee was that all cartelised contracts that had been concluded were required to pay back monies received above the average to the State Treasury (Tweede Kamer der Staten-Generaal, 2003).

In Australia, for example, an investigation by Phillips (2006: p. 1) for the Australian Institute of Public Affairs indicated

[...] contractual arrangements put in place by the Government of Victoria inflated the cost of the Games Village construction by 34 per cent as a result of industrial arrangements with construction unions. In other words, if the Games Village had been built using normal housing contractors, the evidence indicates that the cost of the Games Village would have been 34 per cent less than the actual cost paid for by the taxpayers of Victoria. The extra cost was around $\$ 50$ million on the $\$ 144$ million project.

The US Sentencing Commission (USSC, 2015: p. 310) had also a similar issue and stated

[...] there is near universal agreement that restrictive agreements among competitors, such as horizontal price-fixing (including bid-rigging) and horizontal market allocation, can cause serious economic harm.

The agreements among competitors $[\ldots]$ are almost invariably covert conspiracies that are intended to, and serve no purpose other than to, restrict output and raise prices, and that are so plainly anticompetitive that they have been recognized as illegal per se, i.e., without any inquiry in individual cases as to their actual competitive effect.

The difficulties involved in calculating the 'economic harm' of collusion have been recognised by the USSC (2015: p. 310), which adopts the following simple guideline

The fine for an organization is determined by applying Chapter Eight (Sentencing of Organizations). In selecting a fine for an organization within the guideline fine range, the court should consider both the gain to the organization from the offense and the loss caused by the organization. It is estimated that the average gain from price-fixing is 10 percent of the selling price. The loss from price-fixing exceeds the gain because, among other things, injury is inflicted upon consumers who are unable or for other reasons do not buy the product at the higher prices. Because the loss from price-fixing exceeds the gain, subsection (d)(1) provides that 20 percent of the volume of affected commerce is to be used in lieu of the pecuniary loss under $\S 8 \mathrm{C} 2.4$ (a) (3). The purpose for specifying a percent of the volume of commerce is to avoid the time and expense that would be required for the court to determine the actual gain or loss.

\section{Forensic investigators' analysis of collusion scenarios}

Ongoing investigations have uncovered a network of corruption practices. Among them there were cases related to the Brazilian 
'oil' company, which was the object of a series of plea bargains. As the tender patterns of the League of 16 construction firms were consistent with one another, in most of the cases recorded by the 'oil' company, this provided the grounds for the Federal Police to become suspicious that collusion had taken place. Investigators, however, needed to prove that the bids were indeed collusive and not independent. Consequently, the suspected tender processes were tested statistically by comparing their bid patterns against those that were not under suspicion for similar projects undertaken by the 'oil' company.

The comparison was based on the assumption that in a 'healthy' competitive environment, where competitors have no knowledge of each other's bids and will not match prices, bid behaviour is consistently random. In this instance, independent bids would randomly differ from each other and with the 'oil' company's estimate. However, in the bid pattern involving the cartel, a particular group of bidders had their prices pre-arranged in a consistent pattern, suggestive of collusion. The first burden of proof, therefore, is whether the bids of the League of 16 construction firms (individually or in consortium) are different in their pattern from others'. The pattern being investigated is whether the suspected colluders had repeatedly worked together to influence increases in tender prices artificially. To test whether the successful bidding processes were different from the others, a total of 77 recent projects undertaken by the 'oil' company were randomly selected using the following criteria

- bidding must be under competitive conditions - negotiated tenders were excluded
- projects must be large $(>\mathrm{R} \$ 100$ million (approximately US $\$ 49$ million))

- a minimum of three valid bids must have been received in the course of competition.

The collated data from the 'oil' company were separated into two groups.

n There exists at least one bid from a company that was neither a part nor in partnership with any of the League of 16 construction companies. A total of 55 projects were collated in this category.

- Only the League of 16 companies had bid either independently or in partnership with other companies. Data from a total of 22 projects were obtained.

Extracts of these data are presented in Tables 1 and 2; for the purpose of brevity, the raw data are partially presented in the tables. The following were considered regarding the bid data presented in Tables 1 and 2 .

- Bid values always referred to the initial bid provided by each construction firm (second and third bids were not considered as it was assumed that competitors were aware of the 'oil' company's estimate).

- The values of the 'oil' company's estimate (last line of each process) were always considered to be the most up-to-date estimates. If the 'oil' company, however, incurred an error and subsequently recognised and 'corrected' the estimate, then this figure was used to assess bids. Note that bidders within a

Table 1. Data from the competitive bidding environment $(n=55)$

\begin{tabular}{|c|c|c|c|c|}
\hline Projects & Bids & Competitors & Bid value: $\mathbf{R} \$$ & Difference: \% \\
\hline \multirow[t]{5}{*}{1} & 1 & Company AC & $93354790 \cdot 62$ & -11 \\
\hline & 2 & Company AP & $104231102 \cdot 75$ & 0 \\
\hline & 3 & Company AJ & $112493190 \cdot 56$ & 7 \\
\hline & 4 & Company AK & 115507668.06 & 10 \\
\hline & & 'Oil' company's estimate & $104705330 \cdot 31$ & \\
\hline \multirow[t]{7}{*}{2} & 5 & Company L & $123112669 \cdot 47$ & 11 \\
\hline & 6 & Company AU & $132098400 \cdot 00$ & 19 \\
\hline & 7 & Company BJ & $135174850 \cdot 49$ & 21 \\
\hline & 8 & Company BC & $159000811 \cdot 47$ & 43 \\
\hline & 9 & Company AC & 179604787.87 & 61 \\
\hline & 10 & Company AD & $185474123 \cdot 61$ & 67 \\
\hline & & 'Oil' company's estimate & 111336553.50 & \\
\hline $3-54$ & $11-466$ & - & - & - \\
\hline \multirow[t]{11}{*}{55} & 467 & Consortium (companies P, F and G) & $1348510628 \cdot 00$ & -2 \\
\hline & 468 & Company I & 1398522046.09 & 1 \\
\hline & 469 & Company K & $1434374605 \cdot 26$ & 4 \\
\hline & 470 & Company $\mathrm{H}$ & $1436263727 \cdot 44$ & 4 \\
\hline & 471 & Consortium (companies AC and BA) & 1443259677.76 & 5 \\
\hline & 472 & Company C & $1480622997 \cdot 32$ & 7 \\
\hline & 473 & Company D & 1484925334.04 & 8 \\
\hline & 474 & Consortium (companies $\mathrm{O}$ and $\mathrm{N}$ ) & 1490330786.00 & 8 \\
\hline & 475 & Company CX & 1530536228.03 & 11 \\
\hline & 476 & Company B & $1677065327 \cdot 49$ & 22 \\
\hline & & 'Oil' company's estimate & 1379083853.09 & \\
\hline
\end{tabular}


Table 2. Data from League of 16 's bids $(n=22)$

\begin{tabular}{|c|c|c|c|c|}
\hline Projects & Bid & Competitors & Bid value: $\mathbf{R} \$$ & Difference: \% \\
\hline \multirow[t]{5}{*}{1} & 1 & Consortium (companies $\mathrm{O}$ and $\mathrm{N}$ ) & 193288022.89 & 30 \\
\hline & 2 & Company E & 229849758.60 & 55 \\
\hline & 3 & Company D & $211145000 \cdot 00$ & 42 \\
\hline & 4 & Company $\mathrm{F}$ & $237243062 \cdot 10$ & 60 \\
\hline & & 'Oil' company's estimate & $148352966 \cdot 90$ & \\
\hline \multirow[t]{5}{*}{2} & 5 & Company I & 182376337.63 & 14 \\
\hline & 6 & Company N & $207407097 \cdot 77$ & 30 \\
\hline & 7 & Company C & 210341768.06 & 32 \\
\hline & 8 & Company E & $216625056 \cdot 87$ & 36 \\
\hline & & 'Oil' company's estimate & $159652431 \cdot 74$ & \\
\hline $3-21$ & 9 to 81 & - & - & - \\
\hline \multirow[t]{5}{*}{22} & 82 & Consortium (companies $\mathrm{A}$ and $\mathrm{Al}$ ) & 5937544758.80 & 106 \\
\hline & 83 & Consortium (companies C and J) & $6400000000 \cdot 00$ & 123 \\
\hline & 84 & Company E & $6700000000 \cdot 00$ & 133 \\
\hline & 85 & Consortium (companies I and K) & $6800000000 \cdot 00$ & 136 \\
\hline & & 'Oil' company's estimate & $2876069382 \cdot 78$ & \\
\hline
\end{tabular}

Average exchange rate: $R \$ 1=$ US $\$ 0.49$

healthy competitive environment should not have prior knowledge of the 'oil' company's estimate and therefore any revision to it should not be influenced by the value of bids that had been submitted for consideration.

\subsection{Analysis of the unfettered competitive bids}

The descriptive patterns of the bids that were examined are presented in Table 1. This involved 476 samples from 55 projects in which competitors ranged from three to 21. As projects varied in their size, cost and location and were undertaken at different periods in time, the analysis focused on creating a set of parameters that could facilitate an objective comparison to be undertaken. In particular, the investigators compared the relative difference between the tender prices of the bidders' proposals and the 'oil' company's estimates. The statistical analysis was started by searching for anomalous bids (i.e. outliers). In doing so, it was considered that if a healthy competitive environment existed, then unbiased bids would be randomly dispersed, with some competitors providing bids above the 'oil' company's estimate and others bidding below this amount, as shown in Figure 2.

In a healthy competitive bidding environment, anomalous bids referred to as 'dives' can be observed. Such bids are driven by bidders who offer tender prices that are extremely low (Priemus, 2004). Here contractors may intentionally misrepresent the true costs of line items or involuntary errors. In an event that a diving bid has occurred, the bidder is at the risk of incurring financial losses, and thus, this could derail the 'oil' company's commitment and anticipated outcomes for a project. More importantly, the 'oil' company's procurement policies and Brazilian laws do not accept extremely low bids as viable proposals. Bearing this in mind, such bids were removed from the data set, as exemplified by bid number 5 in Figure 2.

Within the healthy competitive bidding environment, it was observed that many bids were considerably higher than the 'oil' company's initial estimate (bids 4 and 10 in Figure 2 are examples). Such excessive bids can be driven by bidders' quotation errors. In addition, preparing a bid for the sampled projects would have been a considerable task considering their size and complexity (i.e. $>\mathrm{R} \$ 100$ million (approximately US\$49 million)) and therefore risk would have been accordingly priced in their offer.

When difficult bids were encountered, perhaps due to project uncertainty (e.g. aleatoric and epistemic), inexperience or even having limited interest in being awarded a contract, bidders increased their prices by adopting a 'betting bias' attitude to maximise their ability to acquire a gain and minimise their potential loss (Van Der Meulen and Money, 1984). The 'oil' company and the Brazilian legal fraternity have recognised this problem and parameters were adopted to avoid abnormally high bids by eschewing them as being acceptable prices. Adopting the same criteria used for the diving proposals, the high outliers were also excluded from the sample.

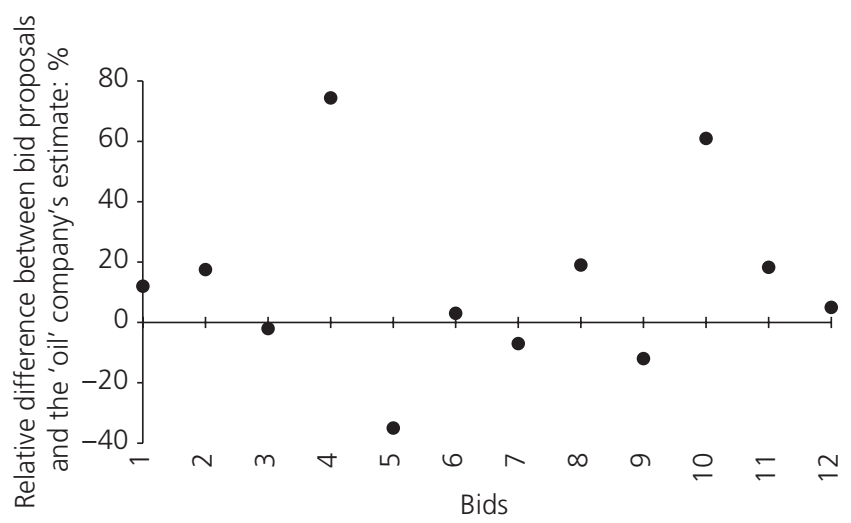

Figure 2. Example of dispersion of bids around the 'oil' company's estimate 
The 'oil' company was supposed to eliminate all bids that were outside the range of -15 to $+20 \%$ around its estimate; yet hindsight reveals that this practice was 'knowingly' overlooked. In examining bids, the investigators therefore applied statistical criteria to determine their admissibility in accordance with the methods proposed by Grubbs (1969). The results of applying Grubbs's methods demonstrated, at a significance level of 5\% (one-tailed), that 14 bids were identified as being outliers as they abnormally differed from other bids that formed part of the tendering process. These samples were therefore excluded from the data set. The remaining 462 bids were sorted by how much they deviated from the 'oil' company's estimate (Figure 3).

After the initial purge of the outliers, there remained cases that abnormally differed from the others (Figure 3). As a result, additional statistical analysis was performed on the grouped data, by using the analysis of outliers in the remaining data set, which has been advocated by Grubbs (1969). It was found that two (in the lower tail) and 21 (in the upper tail) bids may also be considered outliers. Thus, they were also excluded from the data set, which resulted in 439 bids being considered valid.

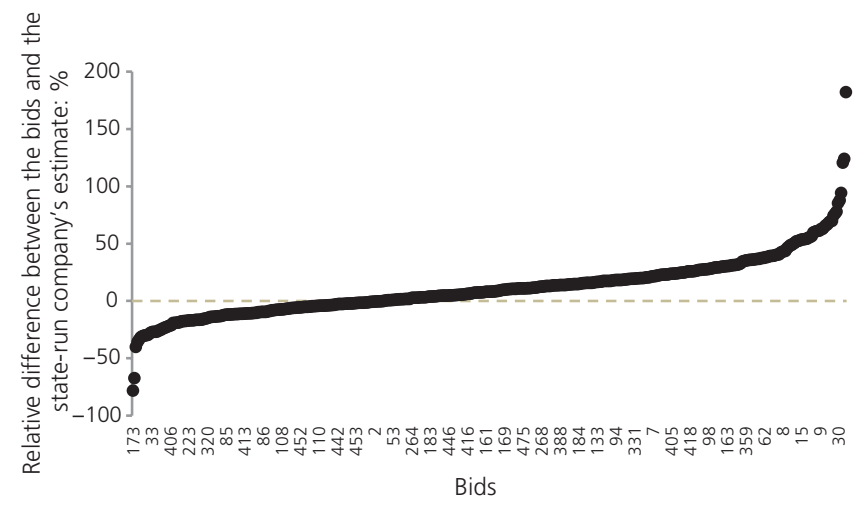

Figure 3. Graphic ordination of the deviations of the unfettered competitive bids

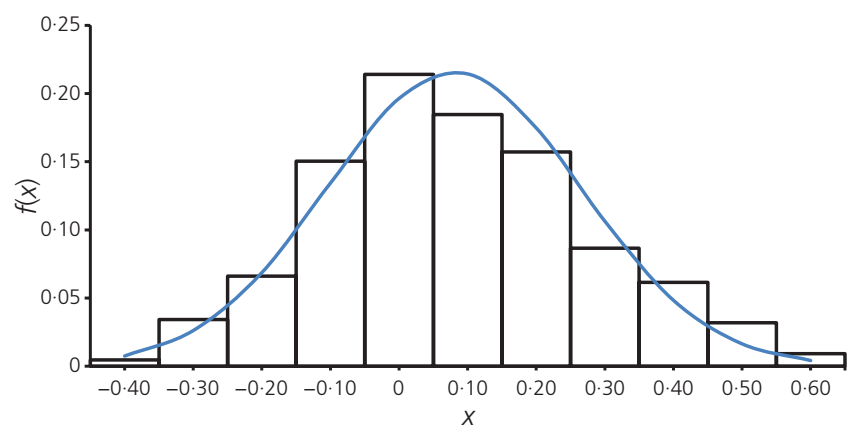

Figure 4. Histogram indicating the competitive bidding process and the distribution selected to represent the data set
Adopting this sanitised data set, the investigators applied the procedure propagated by Love and Sing (2013) and Love et al. (2013) to determine the empirical probability distributions that best describe the data. Using EasyFit software, the 'best-fit' probability distributions were determined by determining their 'goodness of fit', which measures the compatibility of a random sample with a theoretical probability distribution. Tests for following three statistics were undertaken: $(a)$ Kolmogorov-Smirnov $(D)$ statistic, (b) Anderson-Darling statistic $\left(A^{2}\right)$ and $(c)$ chi-square statistic $\left(\chi^{2}\right)$. A description of these statistical tests used to determine a best-fit probability distribution can be found in the paper by Love et al. (2013). Figure 4 presents the histogram of the data and the normal (also referred to as a Gaussian) distribution that can be considered appropriate.

When a $5 \%$ significance level is considered, the suitability of the normal distribution cannot be rejected; this is a simple and wellknown form of distribution. Based on this finding and its general familiarity, it was chosen as the distribution to represent the data set best. Thus, it can be assumed that the general behaviour of the unfettered competitive bids derived from the 'oil' company can be represented by a normal distribution with parameters $\bar{x}=0.082$ and $s=0 \cdot 192$. Table 3 presents the chosen distributions, their parameters and the values of the goodness-of-fit calculations for all tests performed in this paper.

Figure 4 indicates that bids are distributed around the 'oil' company's estimates, with positive and negative deviations, which are balanced and fitted to the normal distribution (as expected from random errors). The 'oil' company's initial estimates provide robust benchmarks for undertaking a comparison with bids submitted under a competitive and anticompetitive tendering environment. Moreover, the average of all bids was $8 \%$ above the 'oil' company's initial estimations; they are therefore deemed to be a reliable estimate of the work that was required to be undertaken.

\subsection{Analysis of the League of 16 bids}

The process of examining the healthy competitive bidding environment was replicated with the same considerations for the League of 16 to examine their bidding behaviour (Table 2). The analysis for the isolated processes indicated that only one case

Table 3. Goodness-of-fit tests for bids

\begin{tabular}{lcc} 
Data set & $\begin{array}{c}\text { Distribution and } \\
\text { parameters }\end{array}$ & $\begin{array}{c}\text { Goodness } \\
\text { of fit }\end{array}$ \\
\hline Unfettered bids & Normal $(\bar{x}=0.08238 ;$ & $D=0.03833$ \\
& $S=0.19245)$ & $A^{2}=0.81719$ \\
League of 16 bids & Normal $(\bar{x}=0.35716 ;$ & $\chi^{2}=7.0404$ \\
& $S=0.23162)$ & $D=0.09956$ \\
& & $A^{2}=0.5879$ \\
Unfettered & Normal $(\bar{x}=-0.10527 ;$ & $\chi^{2}=8.6237$ \\
winner bids & $S=0.13826)$ & $D=0.06862$ \\
& & $A^{2}=0.27596$ \\
& & $\chi^{2}=3.2239$
\end{tabular}


was an outlier. In addition, the grouped data analysis revealed that eleven bids (in the upper tail) were outliers and should be removed from the data set, which resulted in 73 valid bids (Figure 5 ). Once the outliers were removed from the data set, the procedure for determining the best-fit distribution was repeated. Again, the normal distribution was identified as appropriate to describe the data (Figure 6).

At $5 \%$ significance level, the $D, A^{2}$ and $\chi^{2}$ values indicate that the normal distribution could not be rejected and was a suitable fit. The statistical analysis of the bids received is presented in Table 3. The bid deviations for the League of 16 compared to the 'oil' company's estimates are normally distributed with parameters $\bar{x}=0.357$ and $s=0.232$ with the mean value of those from the League of 16 further from the 'oil' company's initial reference by approximately $36 \%$.

\subsection{Comparison between the unfettered competitive and the League of 16 bids}

After identifying the expected bid behaviour for 'extensive competition' and the bidding restricted to the League of 16, the investigators tested the hypothesis that these two bidding groups were different - that is, the behaviour of one group statistically

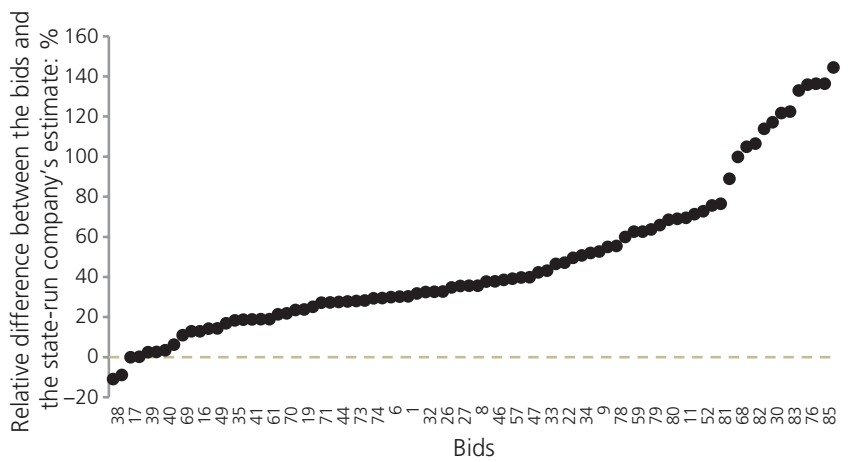

Figure 5. Graphic ordination of the deviations of the League of 16 bids

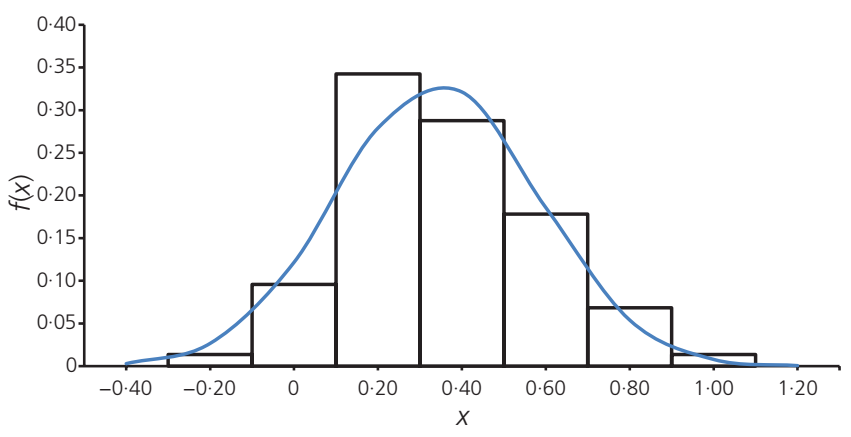

Figure 6. Histogram for the League of 16 bids and the normal distribution selected to represent the data differed from that of the other. This fundamental fact needed to be established to support the conclusion that the bids restricted to the League of 16 were cartelised and had been used to increase the price of the oil projects artificially; this would confirm the content of the widely publicised plea bargains that were being encountered.

The most common statistical test used to solve the presented problem is a two-sample location test, which is referred to as Student's $t$-test. This statistical test can provide a confident answer about the equality of the samples. Thus, a $t$-test was used to compare the two means of the samples so as to determine whether the data sets examined are from the same population or not (the requirements for independence of the samples, their randomness and normality were met). Thus

1. $\mathrm{H}_{0}: \mu_{1}=\mu_{2}$

2. $\mathrm{H}_{1}: \mu_{1} \neq \mu_{2}$

$$
\begin{aligned}
t & =\frac{\left(\bar{x}_{1}-\bar{x}_{2}\right)}{\sqrt{s_{1}^{2} / n_{1}+s_{2}^{2} / n_{2}}}=\frac{(0 \cdot 357-0 \cdot 0824)}{\sqrt{0 \cdot 232^{2} / 73+0 \cdot 192^{2} / 439}} \\
\text { 3. } & =9.60
\end{aligned}
$$

4. $t_{\text {crit }}(\alpha=0 \cdot 05 ; 72) \approx 2 \cdot 00$

As $t>t_{\text {crit }}$, there was sufficient evidence to reject the null hypothesis (the equality of the means). This test points to the conclusion that the behaviour of the bids restricted to the League of 16 was significantly different from the extensive competition bidding practice and thus does not represent the same phenomenon. This statistical evidence, combined with other features already described for the bids restricted to the League of 16, led the investigators to conclude that a cartel was in operation. After identifying the expected behaviour of the healthy competitive bidding environment, the investigators were able to determine the likelihood of bids prepared by the League of 16. The mean and standard deviation obtained from the normal distribution from the healthy bidding sample of construction firms were used by the investigators to calculate the probability of occurrence of each bid restricted to the League of 16 . This probability reflects the deviation of proposals from the 'oil' company's estimate - that is, exorbitant prices would have been unlikely. This calculation was made for the same example shown in Figure 1. The results obtained and presented in Table 4 indicate that the bids submitted had a minimum probability of occurrence.

Considering the analysis that has been presented, the investigators concluded that the bids presented in Table 4, for example, were concerted. Thus, there is almost a zero combined probability of occurrence $P(A \cup B \cup C)$ that this set of proposals presented by 
Table 4. Probability of bid occurrence

$\begin{array}{lccc}\text { Proponents } & \text { Value of bid: RS } & \begin{array}{c}\text { Difference between bid and state-run } \\ \text { company's estimate: \% }\end{array} & \begin{array}{c}\text { Probability of } \\ \text { occurrence: \% }\end{array} \\ \text { Consortium (companies H and B) } & 2878046400 \cdot 00 & 71.3 & 0.05 \\ \text { Consortium (companies C, I and D) } & 2951609120.99 & 75 \cdot 7 & 0.02 \\ \text { Company K } & 3356461140.79 & 99.8 & 0.00 \\ \text { 'Oil' company's estimate } & 1679822711.85 & - & -\end{array}$

Average exchange rate: $\mathrm{R} \$ 1=$ US\$0.49

the bidders has not resulted from deliberate co-operation between the bidders.

\section{Estimating the direct economic harm of collusion}

After proving the existence of the League of 16 cartel, the investigators aimed to estimate the value of the direct economic harm that the 'oil' company had suffered as a result of the lack of competitiveness that had taken place. In doing this, the experiences reported in Australia, the Netherlands and the USA were considered, which have suggested that comparative models are most suitable for estimating losses that can arise from the concerted action of cartels and monopolies.

To estimate the direct harm, the collusive prices of similar projects that had not been suspected of irregularities were compared with one another. This method is akin to that proposed by the European Commission (2013), as it aims to compare the price expectations in a competitive scenario with the prices observed in an anticompetitive scenario. A way to determine the reference scenario is to undertake a simple direct comparison (European Commission, 2013).

In this specific case, it was observed that the 'oil' company's bidding processes were best suited for direct comparison, since concerted and competitive bids occurred concomitantly; essentially, the bidding processes were homogenous in nature. The introduction of new variables was not necessary as they may have been subjected to bias and may not necessarily provide an adequate explanation about the extent of the damage that the cartel has inflicted on the public sector.

A probabilistic model was created to represent the 'noninfringement scenario', which also served as a point of reference. The probabilistic model considers only the winning bids from

Table 5. Data from the winning bids from the competitive bidding environment $(n=55)$

\begin{tabular}{|lrlc|}
\hline Process & Bid & Winning contractor & $\begin{array}{c}\text { Difference between } \\
\text { bid and estimation: \% }\end{array}$ \\
\hline 1 & 1 & Company AC & -11 \\
2 & 5 & Company L & 11 \\
$3-54$ & - & - & - \\
55 & 467 & $\begin{array}{c}\text { Consortium (companies } \\
\text { P, F and G) }\end{array}$ & -2 \\
\hline
\end{tabular}

each unfettered process. Notably, all the bids of the unfettered processes are important for describing the behaviour of healthy competition, but only the winning bids are important to evaluate the direct harm imposed by the collusive contractors. Hence, the procedures associated with the probabilistic analysis for the healthy processes were repeated, with only the winning proposals considered appropriate (excluding the outliers). Table 5 considers the 'statistical winner', which means that if some bid in the lower tail was excluded by the 'oil' company under their internal criterion (which is not a scientific approach) but was not considered an outlier according the statistical tests, it was considered as the preferred winning bid paper. Figure 7 denotes the distribution of bids sorted by those who deviated from the 'oil' company's estimates.

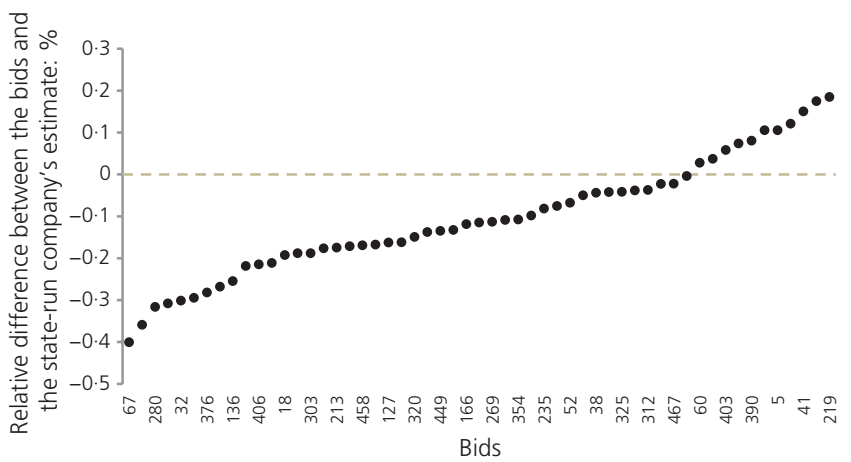

Figure 7. Graphic ordering of the deviations of the winning bids for unfettered processes

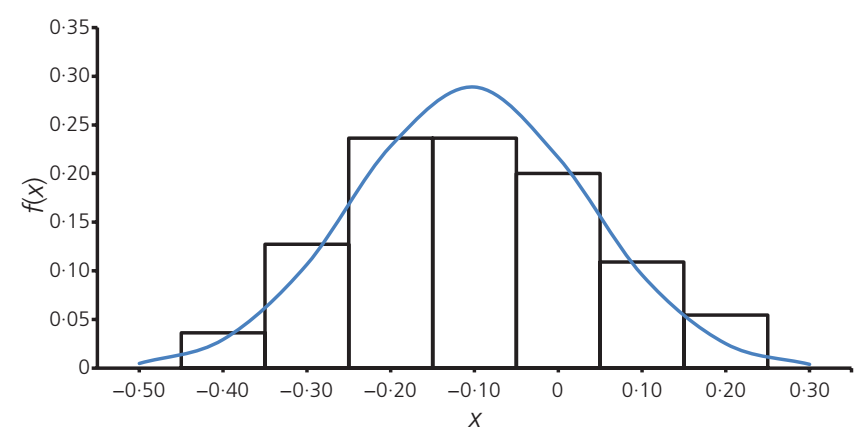

Figure 8. Histogram of the winning bids for the unfettered processes and the adopted normal distribution 
Table 6. Calculation of the direct harm resulting from the cartel action in one contract

\begin{tabular}{|lccccc|}
\hline Estimation of the 'oil' company: R\$ & Expected value: $\mathbf{R} \$$ & Contracted value: R\$ & Direct loss: R\$ & Direct loss: \% \\
\hline 1679822711.85 & 1502885505.59 & 1938191350.00 & 435305844.41 & 22
\end{tabular}

Average exchange rate: $\mathrm{R} \$ 1=$ US $\$ 0.49$

In this case, outliers were not found; the analysis procedure previously described was again undertaken. The analysis revealed that the set of the 55 winning bids derived from the healthy bid environment presented deviations in relation to the 'oil' company's estimates, which can be represented as a normal distribution with parameters $\bar{x}=-0 \cdot 105$ and $s=0 \cdot 138$ (Table 3, Figure 8). At this juncture, it is important to emphasise that bids of all competing participants from the healthy bid environment were on average of $8 \cdot 2 \%$ above the 'oil' company's estimates; the winning bids, however, had been on average discounted by $10.5 \%$ below the 'oil' company's estimate.

The investigators identified above that the expected value for the best bids in a healthy competitive environment was represented by a discount below the 'oil' company's estimate. To estimate the harm that had been caused by the 'oil' company who engaged in collusive activities within a cartelised environment, for example, the contract shown in Figure 1 and Table 4 is examined. It is important to point out that only the direct loss is estimated in this paper. The residual loss (caused by a reduction in competition in other contracts, which naturally raises the negotiated prices, among other factors) and the indirect loss (i.e. the lack of competitiveness that causes a reduction of improvements in production and use of new technologies due to a lack of incentives) were not considered. Needless to say, the values obtained represent the parameters for overpricing, as they reflect economic loss that has been incurred by the 'oil' company as a result of rigging bids. This overpricing may have resulted in excessive profit, bribes, redistribution between the League of 16 and fraudulent outsourced contracts. However, the process for determining the harm of overpricing does not provide a differentiation between the aforementioned corrupt actions, but the total direct costs to the contract that had been let by the 'oil' company. In Table 6, the 'oil' company's estimate and the expected value of the bid that is anticipated based on a healthy competitive environment are provided. It can be seen that the contracted value was significantly higher than the expected value and thus resulted in $22 \%$ direct loss in this instance for this project.

\section{Conclusions}

Corruption is a pervasive issue worldwide. This has been, and continues to be, a demanding and difficult task as there has been an absence of scientific methods that can be used to 'determine' that overpricing takes place. This problem has confronted not only the Brazilian Federal Police but also many other jurisdictions throughout the developing and developed worlds.

Recognising this problem, and suspecting that collusive bidding had occurred in some contracts, a total of 561 bids for 77 projects were analysed. It was revealed that in the suspect contracts, an anticompetitive behaviour had taken place when the OECD's corruption indicators were applied. Aiming to prove this crime scientifically, statistical methods were used to test the hypothesis of collusion. The analysis revealed that the competitive bids were normally distributed $(\bar{x}=0.082$ and $s=0 \cdot 192)$ around the 'oil' company's pre-tender estimates. However, it was revealed that the League of 16's bids, although also normally distributed, were consistently different from random competitive behaviour $(\bar{x}=0.357$ and $s=0.232)$.

The statistical analysis used to determine overpricing and the existence of the League of 16 has provided the Brazilian Federal Police with the ability to redress the presumption of innocence that has been previously considered by judges when seeking to convict perpetrators. The approach has yet to be used by judges but has enabled the Federal Police to provide scientific evidence that overpricing and corruption have taken place.

\section{REFERENCES}

Agencia EFE (2016) Construction Firm Agrees to Return \$285mn Taken in Brazil Corruption. Agencia EFE, Madrid, Spain. See http://www. efe.com/efe/english/business/construction-firm-agrees-to-return-285mn-taken-in-brazil-corruption/50000265-2920785 (accessed 09/05/ 2016).

Barnato K (2014) Why the Petrobras Scandal Is Shaking Brazil. CNBC, Englewood Cliffs, NJ, USA. See http://www.cnbc.com/2014/11/24/ how-the-ptrobras-scandal-is-rocking-brazil.html (accessed 19/05/2016).

Bowen PA, Edwards PJ and Cattell K (2012) Corruption in the South African construction industry: a thematic analysis of verbatim comments from survey participants. Construction Management and Economics 30(10): 885-901, http://dx.doi.org/10.1080/01446193.2012.711909.

Brazilian Federal Police (2016) Operação Lava Jato. Brazilian Federal Police, Brasília, Brazil. See http://www.pf.gov.br/agencia/noticias/ lava-jato (accessed 22/04/2016) (in Portuguese).

Brown J and Loosemore M (2015) Behavioral factors influencing corrupt action in the Australian construction industry. Engineering, Construction and Architectural Management 22(4): 372-389 https://doi.org/10.1108/ECAM-03-2015-0034.

Chotibhongs R and Arditi D (2012) Detection of collusive behavior. Journal of Construction Engineering and Management 138(11): 1251-1258, https://doi.org/10.1061/(ASCE)CO.1943-7862.0000542.

Dorée AG (2004) Collusion in the Dutch construction industry: an industrial organization perspective. Building Research and Information 32(2): 146-156, http://dx.doi.org/10.1080/0961321032000172382.

European Commission (2013) Practical Guide - Quantifying Harm in Actions for Damages Based on Breaches of Article 101 or 102 of the Treaty on the Functioning of the European Union. European Commission, Brussels, Belgium. See http://ec.europa.eu/competition/antitrust/ actionsdamages/quantification_guide_en.pdf (accessed 02/05/2016).

Flyvbjerg B (2016) The fallacy of beneficial ignorance: a test of Hirschman's hiding hand. World Development 84: 176-189 https://doi.org/10.1016/j.worlddev.2016.03.012. 
Grubbs FE (1969) Procedures for detecting outlying observations in samples. Technometrics 11(1): 1-21.

Ko K and Weng C (2011) Critical review of conceptual definitions of Chinese corruption: a formal-legal perspective. Journal of Contemporary China 20(70): 359-378, http://dx.doi.org/10.1080/ 10670564.2011.565170.

Lai KK, Liu SL and Wang SY (2004) A method for evaluating bids in the Chinese construction industry. International Journal of Project Management 22(3): 193-221, https://doi.org/10.1016/S0263-7863(03) 00009-7.

Le Y, Shan M, Chan A and Hu Y (2014) Overview of corruption research in construction. Journal of Management in Engineering 30(4), http://dx.doi.org/10.1061/(ASCE)ME.1943-5479.0000300.

Lopes AO (2011) Superfaturamento de Obras Públicas. Livro Pronto, São Paulo, Brazil (in Portuguese).

Love PED and Sing CP (2013) Determining the probability distribution of rework costs in construction and engineering projects. Structure and Infrastructure Engineering 9(11): 1136-1148, http://dx.doi.org/10. 1080/15732479.2012.667420.

Love PED, Sing CP, Wang $X$ and Tiong R (2013) Determining the probability of cost overruns in Australian construction and engineering projects. Journal of Construction Engineering and Management 139(3): 321-330, https://doi.org/10.1061/(ASCE)CO.1943-7862. 0000575 .

OECD (Organisation for Economic Co-operation and Development) (2002) Fighting Hard-core Cartels: Harm, Effective Sanctions and Leniency Programmes. OECD, Paris, France. See https://www.oecd.org/competition/ cartels/1841891.pdf (accessed 02/05/2016).

OECD (2009) Guidelines for Fighting Bid Rigging in Public Procurement. OECD, Paris, France. See http://www.oecd.org/daf/competition/cartels/ 42851044.pdf (accessed 30/04/2016).

Phillips K (2006) The Cost of Constructing the Commonwealth Games Village - Industrial Relations and the Struggle to Build in Victoria Supplementary Report. Institute of Public Affairs, Melbourne, Australia. See at http://www.ipa.org.au/library/publication/ 1228695356_document_wilcoxgamesvillage2.pdf (accessed 02/05/2016).

Priemus H (2004) Dutch contracting fraud and governance issues. Building Research and Information 32(4): 306-312, http://dx.doi.org/ 10.1080/0961321042000221089.

Rosas R (2015) Prejuízo da Petrobras com corrupção passa de R $\$ 20$ bi, diz procurador. Valor Econômico, 10 September. See http://www.valor. com.br/politica/4264768/prejuizo-da-petrobras-com-corrupcao-passade-r-20-bi-diz-procurador (accessed 02/05/2016) (in Portuguese).

Sandy M (2016) How the Petrobras scandal ensnared Lula - and upturned Brazilian politics. Time, 16 March. See http://ime.com/ 4261712/lula-brazil-petrobras-scandal/ (accessed 30/10/2016).

Sexton J (1989) Controlling corruption in the construction industry: the Quebec approach. Industrial and Labor Relations Review 42(4): 524-535, http://dx.doi.org/10.2307/2524027.

Signor R, Love PED and Olatunji O (2016a) Determining overpricing in Brazilian infrastructure projects: a forensic engineering approach. ASCE Journal of Construction Engineering and Management 142(9) http://dx.doi.org/10.1061/(ASCE)CO.1943-7862.0001156.

Signor R, Love PED, Olatunji O, Marchiori FF and Gripp WG (2016b) A probabilistic method for forensic cost estimating of infrastructure projects. Applied Mathematical Modelling 40(21/22): 9197-9211, https://doi.org/10.1016/j.apm.2016.05.025.

Skitmore RM (2000) Identifying non-competitive bids in construction contract auctions. Omega 30(6): 443-449, https://doi.org/10.1016/ S0305-0483(02)00057-9.

Sohail M and Cavill S (2008) Accountability to prevent corruption in construction projects. Journal of Construction Engineering and Management 134(9): 729-738, https://doi.org/10.1061/(ASCE)07339364(2008)134:9(729).

Tweede Kamer der Staten-Generaal (2002) Eindrapport Parlementaire Enquêtecommissie Bouwnijverheid. Tweede Kamer der StatenGeneraal, The Hague, the Netherlands. See http://parlis.nl/pdf/ kamerstukken/KST64442_2.pdf (accessed 02/05/2016) (in Dutch).

USSC (US Sentencing Commission) (2015) Guidelines Manual. US Sentencing Commission, Washington, DC, USA, section 3E1.1.

Van Der Meulen G and Money A (1984) The bidding game. Journal of Construction Engineering and Management 110(2): 153-164 https://doi.org/10.1061/(ASCE)0733-9364(1984)110:2(153).

Yau C (2016) Bid rigging 'rife' for renovation work on buildings. South China Morning Post, 25 May.

Zarkada-Fraser A and Skitmore RM (2000) Decisions with moral content: collusion. Construction Management and Economics 18(1): 101-111, http://dx.doi.org/10.1080/014461900370997.

Zhang B, Le Y, Xia B and Skitmore M (2016) Causes of business-togovernment corruption in the tendering process in China. Journal of Management in Engineering 33(2), https://doi.org/10.1061/(ASCE) ME.1943-5479.0000479.

\section{How can you contribute?}

To discuss this paper, please email up to 500 words to the editor at journals@ice.org.uk. Your contribution will be forwarded to the author(s) for a reply and, if considered appropriate by the editorial board, it will be published as discussion in a future issue of the journal.

Proceedings journals rely entirely on contributions from the civil engineering profession (and allied disciplines).

Information about how to email your paper online is available at www.icevirtuallibrary.com/page/authors, where you will also find detailed author guidelines. 